\title{
THE INFLUENCE OF PUBLIC PROCUREMENT POLICIES ON THE IMPLEMENTATION OF PROCUREMENT BEST PRACTICES IN SOUTH AFRICAN UNIVERSITIES
}

\author{
WINNIE DLAMINI* \\ INTAHER M AMBE \\ *dlamiw@unisa.ac.za \\ Department of Business Management \\ University of South Africa (Unisa)
}

\begin{abstract}
The relationship between public procurement policies and procurement best practices (PBPs) in higher education institutions is inevitable. Higher education institutions (HEls) in South Africa play a crucial role in contributing to the economic, social and environmental development of the country. Hence the implementation of PBPs has a key role in creating a competitive advantage for higher education. The purpose of this article is to determine the influence of public procurement policies on the implementation of PBPs in the public HEls in South Africa. The article employs a theoretical review of related literature on public procurement and PBPs. The article articulates that public procurement policies influence the implementation of PBPs in public HEls in South Africa.
\end{abstract}

\section{INTRODUCTION}

Procurement plays a key role in contributing to the bottom line of any organisation (Rudzki, Smock, Katzorke \& Stewart, 2006: 4). Conversely, the procurement function has been conventionally referred to as a non-strategic function, often subordinated to the finance department in the public or service sectors (Baily, Farmer, Crocker, Jessop \& Jones, 2008 : 5). According to Burt, Petcavage and Pinkerton (2010: 2), procurement function has always been accountable for a huge portion of the total cost that organisations incurred and held responsible for most of the quality and outages issues. Not surprisingly, over the years the procurement function slowly gained recognition as organisations realised that the reactive ways do not always give the organisation competitive advantage in turbulent markets (Schuh, Raudabaugh, Kromoser, Strohmer \& Triplat, 2012: 3). The competitive advantages can be attained and sustained through the application of procurement best practices (PBPs) (Hugo \& Badenhorst-Weiss, 2011: 6).

The employment of PBPs has vital economic and political implications in the public sector (Odhiambo \& Kamau, 2003: 10). The practices are increasingly being recognised as significant drivers for successful management of public resources and a number of countries have become more aware of its importance (Mahmood, 2010: 103). Bolton (2006: 183) has 
asserted that procurement in the South African public sector is of particular significance as it is used as a policy tool. This is due to the discriminatory and unfair practices of the apartheid era which favoured large and established businesses over their smaller counterparts. After the democratic government came into effect in 1994, procurement systems were granted constitutional status (Bailey, Cloete \& Pillay, 2011: 36). Subsequently, procurement systems in South Africa promote aims which are arguably, secondary to the primary aim of procurement such as using procurement to promote social, industrial or environmental policies (Bolton, 2006: 193). To date all organs of states are required to acquire goods and services in a manner that is fair, equitable, transparent, competitive and cost effective as indicated in section 217 of the 1996 Constitution.

Therefore, public HEls in South Africa as organs of state which are autonomous establishments (Mthembu, 2009: 9) conduct their procurement as entrenched in the Constitution. Even though public HEls are autonomous institutions, they are required to conform to cooperative governance. Consequently, they manage procurement according to the Public Procurement Policies (National Treasury, 2005: 5). They are also accountable to the public as they are mostly funded by public funds; hence they have the moral responsibility for the social and economic needs of the country (Bailey et al., 2011: 37). It is for this reason that procurement in SAPHEls plays a crucial role in the country's effort of redressing the imbalances of the past (McCruden, 2007).

However, compliance with public procurement policies makes it difficult for the SAPHEls to employ effective procurement strategies that would be more responsive to changes in global knowledge and labour market demands (Devarajan, Monga \& Zongo, 2011: 134). Bolton (2009: 22) also asserted that the rigidity of public procurement policies has made public procurement more complex. This has led to SAPHEls facing difficulties in employing PBPs for competitive advantage. Hence there is the need to study the influence of public procurement policies in the implementation of PBP in the SAPHEls.

Against this background the purpose of this article is to analyse the impact of public procurement policies on the application of the PBPs in the SAPHEls. The article begins by providing the research strategy and then moves on to an understanding of PBPs. It presents public procurement policies that influence the implementation of PBPs, and challenges in SAPHEls, as well as procurement in higher education.

\section{RESEARCH STRATEGY}

The article is exploratory in nature and involved a theoretical review of related literature on PBPs and the policies on public procurement in the SAPHEls context. Secondary data analysis such as literature as a foundation of PBPs was employed. South African procurement policies 
and regulations were used as a source for extracting procurement policies and regulations for SAPHEls. Thereafter, public procurement policies and PBPs were analysed to ascertain whether the public procurement policies had any effect on the implementation of PBPs in the SAPHEIs.

\section{REVIEW OF PROCUREMENT BEST PRACTICES}

This section of the article presents the definition of procurement, provides a brief overview of PBPs and further expounds on their development and importance.

\section{Definition of procurement}

Procurement is a strategic, systematic process of ensuring that maximum value is delivered to the organisation, through identification and selection of suitable and competent suppliers, negotiating, contracting, conducting supply market research, fostering supplier measurement and systems development (Handfield, Monczka, Guinipero \& Patterson, 2011: 8). Burt et al. (2010: 6), defined procurement as a conciliator stage between purchasing and supply management, as a result of the growth and broader scope of procurement. The development of procurement has led to organisations establishing a variety of procurement practices when acquiring the same materials and services (Wellstein \& Kieser, 2011: 683).

The endeavour of maximisation of the organisation's resources for competitive advantage resulted in the evolvement of the PBPs (Garcia, 2009: 8). According to Gilbert (2008: 1055), a best practice is a technique or methodology that through experience and research has proven to reliably lead to a desired result. Tucker, Nembhard and Edmondson (2007), defined best practice as 'a set interrelated work activities utilised by individuals or a body of knowledge that has repeatedly demonstrated yielding optimal results'. However, Gilbert (2008: 1055) warns that it is not easy to define PBPs as organisations and individuals differ considerably.

\section{Growth and development of purchasing and the evolvement of procurement best practices}

As indicated in the previous section, PBPs emerged as purchasing advanced from being a tactical function to a strategic level of supply management. Generous research on the topic was effected, for example, such as Kraljic (1983), who proclaimed that purchasing should become supply management. PBPs are adopted by organisations that have progressed from transactional purchasing to supply management level (Cox \& Hines, 1997; Nelson, Moody \& Stegner, 2005; Bernardes \& Zsidisin, 2008). They used PBPs as enablers to reach the supply management level.

Subsequently, many procurement models have been contrived on the evolution stages and development of the purchasing. Burt (1994: 11), for example, wrote about proactive 
procurement's ability to increase profits, productivity and quality. Reck and Long (1988: 3-6), examined the strategic role of purchasing, and developed a four-stage purchasing development model which include the passive, independent, supportive and integrative stages. Syson (1992) perceived purchasing to be divided into three areas, namely transaction, commercial and proactive stages. Nelson, et al. (2005: 71) compared the procurement evolutionary stages to the educational development from primary to post-graduate level. Later, Burt et al. (2010: 18) proposed practices that should be targeted towards growth in the supply management echelon.

Thus, developing and sustaining PBPs is not an easy task for organisations (Fitzgerald, 2002). This is because the adoption of the practices is time consuming, entails breaking down barriers in internal resistance, demands a new approach to suppliers, and demands considerable investment in good leadership, people, training, analysis, measurement and technology (Booth, 2010: 70). Hence, not all modern organisations have fully adopted PBPs in order to reap the massive prospects that are brought about by its application (Rudzki, et al., 2006: 4).

It must be emphasised though, that some organisations that have realised the potential that the procurement function has, sometimes do not conserve the practice and eventually remain stuck on the elementary stages of development (Nelson, et al., 2005: 12). However the few that constantly strive to embrace PBPs rely on the expertise of the procurement function to drive profitability improvements programmes that translate to innovation and increased value creation (Cousins, Lamming, Lawson \& Squire, 2008: 8). Sollish and Semanik (2007: 2) agree with the notion that organisations that conduct their procurement according to best practices align their procurement strategies with their overall organisational goals, thereby creating and sustaining a competitive advantage for the whole organisation (Ireland \& Webb, 2007).

It is for this reason that Lau (2007) maintains that HEls should look for ways to remain competitive in today's ever-changing environment even though they are non-profit seeking organisations. Most literature usually cites best practice theories for profit-seeking organisations. Comm and Mathaisel (2008) have also come to the conclusion that HEls should employ PBPs in a similar manner to how it is done in the private sector. This means that higher education management should hold in equal esteem the significant value that management can make (Drucker, 1998) in driving the HEls beyond providing services at a cost below the competition and strive to employ PBPs. Table 1 illustrates the list of PBPs. 
Table 1: Lists of procurement best practices

\begin{tabular}{|c|c|c|c|}
\hline & Baily, et al. (2008: 32) & Nelson, et al. (2005: 28) & Smock, et al. (2007: 7) \\
\hline $\begin{array}{l}\text { Procurement } \\
\text { best practices } \\
\text { (PBPs) }\end{array}$ & $\begin{array}{l}\text { Identify and work with key } \\
\text { suppliers. } \\
\text { Develop openness and } \\
\text { transparency. } \\
\text { Align systems with strategic } \\
\text { initiatives. } \\
\text { Articulate mutual goals. } \\
\text { Forge partnerships where } \\
\text { appropriate. } \\
\text { Use complementary } \\
\text { competencies. } \\
\text { Employ dedicated } \\
\text { complementary assets. } \\
\text { Employ appropriate } \\
\text { technology. } \\
\text { Use appropriate } \\
\text { e-technology/systems. } \\
\text { Share competencies and } \\
\text { resources. } \\
\text { Establish common } \\
\text { language. } \\
\text { Emphasise mutual benefits. } \\
\text { Implement kaizen. } \\
\text { Remove decoupling points. } \\
\text { Empower individuals. } \\
\text { Empower suppliers. } \\
\text { Focus on customer needs. } \\
\text { Pursue and eliminate waste. } \\
\text { Consider core/non-core } \\
\text { questions. } \\
\text { Build knowledge base. } \\
\text { Be responsive, and ready to } \\
\text { change. }\end{array}$ & $\begin{array}{l}\text { Cost management. } \\
\text { Supplier development. } \\
\text { Value analysis/ value } \\
\text { engineering. } \\
\text { Non-traditional purchasing. } \\
\text { Supplier quality circles. } \\
\text { Training. } \\
\text { Supplier information } \\
\text { sharing. } \\
\text { Supplier conference. } \\
\text { Supplier performance } \\
\text { reporting. } \\
\text { Supplier surveys. } \\
\text { Delivery improvement. } \\
\text { Tool and technical assistance } \\
\text { centres. } \\
\text { Supplier Support (SWAT) } \\
\text { Teams. } \\
\text { Loaned executives. } \\
\text { Early supplier involvement. } \\
\text { New model development } \\
\text { group. } \\
\text { Written strategy for every } \\
\text { supplier, every part/ } \\
\text { commodity. } \\
\text { Strategic planning and } \\
\text { administration. } \\
\text { Career path planning } \\
\text { and academic outreach } \\
\text { programmes. } \\
\text { Purchasing systems. }\end{array}$ & $\begin{array}{l}\text { Strategic sourcing. } \\
\text { Negotiations management. } \\
\text { All spend categories in } \\
\text { scope. } \\
\text { Risk management. } \\
\text { Partnership with suppliers. } \\
\text { Supplier recognition. } \\
\text { Collaboration with suppliers. } \\
\text { Contract management and } \\
\text { supplier-centric strategies. } \\
\text { Cost reduction planning/ } \\
\text { tracking. } \\
\text { Budget adjustment to } \\
\text { preserve cost reductions. } \\
\text { Consortium buying. } \\
\text { Low-cost-country sourcing. } \\
\text { Asset recovery. } \\
\text { Selective outsourcing. }\end{array}$ \\
\hline
\end{tabular}

Having examined PBPs, the article now turns to public procurement in higher education.

\section{PROCUREMENT IN PUBLIC HIGHER EDUCATION INSTITUTIONS IN SOUTH AFRICA}

This section of the article focuses on recent key procurement acts and policies that influence SAPHEls. The section commences by discussing policies in general. Thereafter, the public procurement Acts and policies that affect public HEls in South Africa will be presented.

\section{Public procurement policies}

Policies are important in any organisation as they provide principles and procedures or guidelines that should be followed when carrying out certain activities (Monczka, Handfield, Giunipero, Patterson \& Waters, 2010: 136). However, without diminishing the pivotal role of policies, in some instances policies can restrict flexibility and innovation (Handfield, et al., 2011: 90). It is on the basis of the latter statement that this research was instituted: 
to investigate whether, and to what extent, do public procurement policies affect the implementation of PBPs in the SAPHEls.

According to Arrowsmith and Kunzlik (2009: 9), public procurement is 'the process whereby government bodies purchase from the market the goods, works and services that they need'. In the public sector, large amounts are spent on goods and services because of the sector's gigantic size (Baily et al., 2008: 58). It is for this reason that the South African government introduced a number of legislations governing procurement spending. Most of the legislations, including the Higher Education Act emerged from the Constitution of the Republic of South Africa (1996), which insisted that the education system should be transformed and democratised in a manner that values human dignity, equality, human rights and freedom, non-racism and non-sexism.

Unfair and discriminatory public procurement policies in South Africa preferred large and established businesses to small businesses, before the birth of democracy in 1994. Therefore public procurement in South Africa had to undergo transformation through the introduction of procurement reforms initiated from 1995 (Migiro \& Ambe, 2008: 231). This was the government's plan to accelerate economic growth and equal distribution, reduce poverty, supply scarce skills and assist in empowering all citizens in South Africa (Bolton, 2006: 193). The procurement reform processes were embedded in section 76(4) (C) of the Public Finance Management Act (PFMA) and the Preferential Procurement Policy Framework Act (Act No 5 of 2000) (PPPFA) (SAMDI, 2005). In the public sector, public procurement policies have since its inception been established to promote emerging small businesses (Bannock \& Peacock, 1989). The South African government also adopted the practice of introducing the BroadBased Black Economic Empowerment Act 53 of 2003 (BBBEEA) and the National Small Business Act 102 of 1996.

In order to stimulate the reforms, in 2001 the National Treasury completed a joint country procurement assessment review (CPAR) with the World Bank to assess procurement practices throughout the public sector. The CPAR identified certain shortcomings in practices relating to governance, interpretation and implementation of PPPFA and its associated regulations (National Treasury, 2003: 2). The inadequacies compelled the authorities to robustly establish practices that are efficient and effective. It was for this reason that the supply chain management (SCM) was introduced in the South African public sector (Mkhize, 2004). SCM aims to add value at each stage of the process from the demand of goods or services to their acquisition, managing the logistics process and finally, after use, to the disposal of the goods. In the education sector, procurement concentrated mostly on streamlining operations through which teaching materials are delivered to students (Migiro \& Ambe, 2008: 231). In so doing, it addressed deficiencies of the current public practices related to procurement, contract management, inventory and asset control as well as obsolescence planning (Holmberg, 2000). 
The transformations were set up to advance principles of good governance and establish a preferential system to address socio-economic issues (Ambe, 2009: 427). However, the formulation of the policies in procurement was not congruent with the government's objectives and strategies. This situation led to the launch of the SCM policy by the National Treasury which was aimed at presenting world-class best practices (National Treasury, 2005). Even though these initiatives were intended for the public good, it appears they influence the implementation of PBPs in public HEls. Public HEls, based on the SCM policy, are expected to develop a customised SCM policy to suit their needs. Some of the SCM policy and regulations that influence the application of procurement in public HEls include:

- Public Finance Management Act 1 of 1999 (PFMA)

- Preferential Procurement Policy Framework Act 5 of 2000 (PPPFA)

- General Procurement Guidelines

- Policy to Guide Uniformity in Procurement Reform Processes in Government

- Broad-Based Black Economic Empowerment Act 53 of 2003 (BBBEEA)

- National Small Business Act 102 of 1996

- Codes of Good Practice as published on 9 February 2007

- Promotion of Access to Information Act 2 of 2000

- Prevention and Combating of Corrupt Activities Act 12 of 2004

- Insolvency Act no. 8 of 1936, as amended, and the

- Confidentiality of the Procurement Process.

These acts and policies are the most influential in the procurement function of SAPHEls.

\section{Procurement practices in the South African public higher education institutions}

HEls are predominantly service-oriented institutions (Burt, Dobler \& Starling, 2003: 578). Since the need for services procurement is the fastest growing sector, the procurement in SAPHEls needs to be managed efficiently and effectively. Procurement spending in South Africa higher education is estimated at R40 million per annum (National Treasury, 2012: 353). Substantial cost drivers in these institutions are consumed mostly by workforce salaries shared between the professional academic and the administrative staff. Other procurement requirements of SAPHEls include costs associated with research and development activities. The Gross Domestic Product (GDP) in South Africa on research and development was estimated at $0.9 \%$ in 2012. Other costs include infrastructure maintenance, administration, library materials, travel expenses, printing services, hospitality services and municipality fees.

Paradoxically, traditionally, institutional procurement has not been stimulated to manage procurement costs as much as in the private sector (Burt, et al., 2003: 579). However, recently, the circumstances have changed considerably. The government and the taxpayers have become more conscious of the rising costs of higher education (Burt, et al., 2003: 579). Therefore costs containment techniques become a crucial element in the procurement 
function of the SAPHEls. One method that confines cost is the introduction of PBPs, which involve among other practices, strategic sourcing, collaborations and outsourcing (Comm \& Mathaisel, 2008).

As indicated before, procurement in SAPHEls is entrenched in the Constitution of South Africa, section 217 of 1996 . SAPHEls use the procurement policies to comply with the procedures and legislation of South Africa. The policies of SAPHEls promote proficient supply of goods and services by means of among others, PBPs such as consortium buying, collaborations, appropriate technology and training to be efficient and offer best service to their stakeholders at minimum cost. Furthermore, SAPHEls embrace ethical procurement and compel compliance though the Ethical Code of Conduct. It is for this reason that the SAPHEls apply public procurement policies such as the PFMA 1 of 1999; the PPPFA 5 of 2000; the General Procurement Guidelines, the Policy to Guide Uniformity in Procurement Reform Processes in government, and the BBBEEA 53 of 2003 in order to support the small entrepreneurs.

SAPHEls procure some of their materials and services through the Purchasing Consortium Southern Africa (PURCO), which is an association that assists universities to acquire economies of scale for products and services that that are common and frequently needed by universities. SAPHEls also encourage beneficial competition of tendering processes for the procurement of goods and services that are above R1 million by using the 90/10 preference point system. Suppliers are required to register on the university's procurement database in order to get the opportunity of being selected to render services. The policy of 'value for money' is applied by using the 80/20 preference point system for items and services from R35 000 up to R1 million. However with goods and services of lower value and purchases of less than R35 000 they use the three quotation system (National Treasury, 2011: 5).

\section{Challenges faced by South African public higher education institutions}

SAPHEls are faced with many challenges, among them the rapidly changing patterns of society (Comm \& Mathaisel, 2008). Other challenges include: (1) competition with private institutions; (2) reduced funding (the proportion of total state finance committed to SAPHEls dropped from 4\% in 1999 to $2.5 \%$ in 2007 according to the International Education Association of South Africa [IEASA] (2009:18), (3) rising operational costs, which have always been a concern in SAPHEls for the stakeholders such as the consumers which include the student and parent population (tuition fees), the university authorities as suppliers of higher education and the government through the subsidy funding (Immerwahr \& Johnson, 2007). Moreover SAPHEls face uneven quality across the sector, low post-graduate numbers, high student drop-out rates, and the need to attract and retain more academics and managers who are leaving the profession for better salaries in the government sector and corporate world (IEASA, 2009). 
Another critical issue that challenges procurement in HEls is the mindset that organisations have about procurement (Albert, 2012). Albert affirms that procurement is still regarded as a non-strategic function in most organisations and in some instances the function abandons research in procurement as it is considered to be complicated. However Albert (2012) believes that procurement officials in HEls can measure their success by:

1) 'how much they help researchers in the university to procure the material and services

2) how much academics freely ask procurement officials for help and

3) the low numbers of incidents that require the function to step in and solve poor procurement practices.'

Following the discussion presented above, it is evident that public procurement policies are inevitable and essential to SAPHEIs.

\section{THE INFLUENCE PUBLIC PROCUREMENT POLICIES ON THE IMPLEMENTATION OF PROCUREMENT BEST PRACTICES}

With the recent economic downturn it has becomes necessary that the public procurement policies influence on the implementation of PBPs is investigated. This is because the application of PBPs has the potential of yielding positive outcomes, such as cost reductions across the supply chain, while PBPs such as strategic alignment of socio-economic goals, lean supply, and the use of e-procurement, cooperative procurement and supplier become essential for public HEls. Table 2 reflects how the public procurement policies influence the implementation of PBPs in the SAPHEIs.

The rationale of the table is to highlight the significance of aligning the public procurement policies and Acts and the PBPs because they influence each other. However, it becomes important to point out that public procurement policies should be formulated well in order to permit the implementation of the PBPs, especially in South Africa. This is because inconsistencies hinder the implementation of PBPs, thereby causing inefficiencies even in the SAPHEls. Also, it becomes apparent that the availability of policies and procedures do not lead to compliance since in some instances policies are unclear, fragmented or non-specific. For example section 217 (1) of the Constitution states that all 'organs of state' must conduct procurement in a manner that is fair, equitable, transparent, competitive and cost effective.

Mdumbe (2003: 28) questions the basis for classifying universities as organs of the state as they do not function at government level. Universities as 'public institutions' are largely funded by public funds and therefore have a socio-economic responsibility to contribute positively towards the national policies. But universities are not bound by the procurement legislation and policies as they are deemed to be performing a strategic function that requires flexibility (Bolton 2010: 108). Bolton also emphasises that even though all the organs of the 
state use the prescribed procurement framework, not all of them are directly bound by it. Universities fall under the unlisted category (that means they are excluded in the procurement Act. Therefore it is for this reason that Mdumbe (2003: 9) also asserts that the definition of organs of the state is not well crafted.

Furthermore section 217 (2) does not provide the link with section 239, which defines organs of state. Also, in section 239, there is no precise indication of where to find the scheduled list of organs of state. In addition, in the schedule list, there is no information about the whereabouts of the unlisted public entities. The fragmentation of the information leads to misinterpretation when the linkages are not provided. Moreover, the information that unlisted public entities are exempted from subsection (2) would be overlooked as no mention is made next to it in the subsection. Even though HEls are autonomous institutions, they still have to submit to the cooperative governance prescription. The prescription contradicts the notion of their exclusion.

Table 2 presents the public procurement Acts and the corresponding PBPs in SAPHEls.

Table 2: Public procurement Acts and policies and the corresponding PBPs in SAPHEls

\begin{tabular}{|l|l|l|}
\hline $\begin{array}{l}\text { Public procurement Acts } \\
\text { and policies }\end{array}$ & Procurement best practices & Influence on the implementation by SAPHEIs \\
\hline $\begin{array}{l}\text { Section } 217 \text { of the } \\
\text { Africa (Act 108, 1996) }\end{array}$ & $\begin{array}{l}\text { Strategic commitment of } \\
\text { senior authorities }\end{array}$ & $\begin{array}{l}\text { Provide a strategic framework for public entities } \\
\text { including SAPHEls on which to align their } \\
\text { broad socioeconomic policy objectives. The } \\
\text { section offers positive principles of fairness, } \\
\text { equity, transparency, competitiveness and cost } \\
\text { effectiveness. }\end{array}$ \\
\hline $\begin{array}{l}\text { Section } 239 \text { of the } \\
\text { Constitution of South } \\
\text { Africa }\end{array}$ & $\begin{array}{l}\text { Organisational structure and } \\
\text { clear reporting lines }\end{array}$ & $\begin{array}{l}\text { SAPHEls are autonomous organs of state: not } \\
\text { bound by public procurement policies but } \\
\text { still responsible for the public good because } \\
\text { they are subsidised by public funds. SAPHEls } \\
\text { procurement functions are still subordinated } \\
\text { to the finance department, and somehow } \\
\text { required to preferential policies which } \\
\text { sometimes hinder the implementation of PBPs. }\end{array}$ \\
\hline $\begin{array}{l}\text { Public Finance } \\
\text { Management Act } 1 \text { of } \\
\text { (1999) }\end{array}$ & $\begin{array}{l}\text { Strategic sourcing, lean } \\
\text { supply, collaborations and } \\
\text { supply chain management }\end{array}$ & $\begin{array}{l}\text { Promotes and controls good financial } \\
\text { management in order to maximise service } \\
\text { delivery through the effective and efficient use } \\
\text { of the limited resources. }\end{array}$ \\
\hline $\begin{array}{l}\text { Preferential Procurement } \\
\text { Policy Framework Act } 5 \text { of } \\
\text { 2000 (PPPFA) }\end{array}$ & $\begin{array}{l}\text { Develop openness and } \\
\text { transparency and articulate } \\
\text { mutual goals }\end{array}$ & $\begin{array}{l}\text { Provide an implementation framework within } \\
\text { which preferential procurement policies are to } \\
\text { be implemented. Even though SAPHEls are } \\
\text { not listed in the PPPFA schedule, they are still } \\
\text { expected to contribute to the development of } \\
\text { emerging entrepreneurs. }\end{array}$ \\
\hline $\begin{array}{l}\text { Broad-Based Black } \\
\text { Economic Empowerment } \\
\text { Act 53 of 2003 (BBBEEA) }\end{array}$ & $\begin{array}{l}\text { Supplier development } \\
\text { programmes and } \\
\text { empowerment of individuals } \\
\text { and suppliers }\end{array}$ & $\begin{array}{l}\text { A legislative intervention to create a fairer } \\
\text { distribution of wealth and opportunity. SAPHEls } \\
\text { are indirectly responsible for promoting } \\
\text { social and economic relief to previously } \\
\text { disadvantaged communities. }\end{array}$ \\
\hline
\end{tabular}




\begin{tabular}{|l|l|l|}
\hline $\begin{array}{l}\text { Codes of Good Practice } \\
\text { as published on 9 } \\
\text { February 2007 }\end{array}$ & $\begin{array}{l}\text { Establish a common } \\
\text { language }\end{array}$ & $\begin{array}{l}\text { Ensure that integrity is applied in all business } \\
\text { relationships both internally and externally. }\end{array}$ \\
\hline $\begin{array}{l}\text { Prevention and } \\
\text { Combating of Corrupt } \\
\text { Activities (Act 12 of 2004) }\end{array}$ & Risk management & $\begin{array}{l}\text { Proclaims that corruption is an offence and } \\
\text { introduces a register that restricts corrupt } \\
\text { enterprises and activities: also forces authorities } \\
\text { to report corrupt transactions. }\end{array}$ \\
\hline
\end{tabular}

\section{CONCLUSION}

This article was designed to explore the impact of public procurement policies on the application of PBPs in the SAPHEls. The article was exploratory in nature and involved a theoretical review of related literature on PBPs and the policies on public procurement in the SAPHEI context. The article started by providing a description of PBPs and presented their growth and development. It then offered public procurement policies, and theirconnectedness to procurement practices in SAPHEls. Also, challenges faced by SAPHEIS were supplied which justifies the employment of PBPs. Subsequently, the public procurement policies that affect the implementation of PBPs were highlighted. Thereafter the influence of public procurement policies was explored in the SAPHEls with reference to the implementation of PBPs. Analysis of the procurement policy reveals that in some instances the policies are unclear, fragmented, contradictory and thus inconsistently applied by the SAPHEls.

Based on the reviews, public procurement policies that affect the implementation of PBPs in public HEls in South Africa were put forward. The article recommends that authorities should be responsive to the needs and challenges of the SAPHEls by aligning public procurement policies and PBPs. Also acknowledged was the indispensable relationship that exists between the public procurement practices and the SAPHEls. The reality is unfortunately that there is an inverse relationship between public procurement policies in the implementation of best practices. This is because it is difficult to get 'value for money' against the restrictive socioeconomic national policies of procurement.

Therefore, it is also not surprising that SAPHEls conduct their procurement according to the public procurement policies to meet economic, equity and social justice obligations. However due to the challenges mentioned above, it becomes apparent that the application of PBPs will always tend to be a test unless attended to immediately by the stakeholders. Also, uncertainty with regard to the extent to which SAPHEls have to comply with the Acts and policies surfaced. Therefore, it is advisable that the policymakers revisit the manner in which public procurement policies are structured in order to make them clearer and more connected for better application by the relevant stakeholders.

Finally, SAPHEls as the custodians of information, need to apply PBPs for proper management of public funds (Albert, 2012). It is their responsibility to negotiate with the policymakers with 
regard to aligning public procurement policies with the PBPs in order to be sustainable in the long term. Even though the implementation and retention of PBPs is not a simple undertaking and requires significant investment, it should be noted that it is a worthy commission. 


\section{REFERENCES}

Albert, A. 2012. University buying must help push the research boundaries. Supply management. com. Available from: http://www.supplymanagement.com/2012/universitybuying-must-help-push-research-boundaries/. (Accessed 20 September 2012).

Ambe, I.M. 2009. Evaluation of the implementation of public sector supply chain management and challenges: A case study of the central district municipality, North West Province, South Africa. African Journal of Business Management, 2 (12): 230-42.

Arrowsmith, S. \& Kunzlik, P. 2009. Public procurement and horizontal policies in EC law: general principles. Cambridge University Press, New York.

Bailey, T. Cloete, N. \& Pillay, P. 2011. Higher education institutions and economic development in Africa. Pretoria: CHET (Council for Higher Education and Training).

Baily, P. Farmer, D. Crocker, B. Jessop, D. \& Jones, D. 2008. Procurement principles and Management. Pearson Education, Prentice Hall.

Bannock, G. \& Peacock, A. 1989. Governments and Small Business. Paul Chapman Publishing Ltd, London.

Bernardes, E.S. \& Zsidisin, G.A. 2008. An examination of strategic supply management benefits and performance implications. Journal of Purchasing \& Supply Management 14: 209-19.

Bolton, P. 2006. Government procurement as a policy tool in South Africa. Journal of Public Procurement, PrAcademics Press 6(3): 193-217.

Bolton, P. 2009. 'When can bidders with bad track records be rejected?' Local Government Bulletin, 11: 22-24.

Bolton, P. 2010. The regulation of preferential procurement in state-owned enterprises. Journal of South African Law, 101-18.

Booth, C. 2010. Strategic procurement: organising suppliers and supply chains for competitive advantage. Kogan page Limited, USA.

Burt, D. 1994. Proactive Procurement. Prentice-Hall, New York. 
Burt, D.N. Dobler, D.W. \& Starling, S.L. 2003. World Class Supply Management: The key to Supply Chain Management. McGraw-Hill, New York.

Burt, D. Petcavage, S. \& Pinkerton, R. 2010. Supply management. McGraw-Hill/Irwin, New York.

Comm, C.L. \& Mathaisel, D.F.X. 2008. Sustaining higher education using Wal-Mart's best supply chain management practices. International Journal of Sustainability in Higher Education. 9 (2): 183-89.

Cousins, P., Lamming, R., Lawson, B. \& Squire, B. 2008. Strategic Supply Management: principles, theories and practice. Prentice Hall. England.

Cox, A. \& Hines, P. 1997. Advanced Supply Management-The Best Practice Debate. Boston. $\mathrm{U}$ : Earlsgate press.

Devarajan, S. Monga, C. \& Zongo, T. 2011. Making higher education finance work for Africasuper. Journal of African Economies, 20(3): iii-154.

Drucker, F.P. 1998. Leading organisations: perspectives for a new era. Sage Publications: Thousand Oaks, California.

Fitzgerald, K.R. 2002. Best practices in procurement. Achieving supply chain excellence through technology. ASCET, 4. Available from: http://www.nevi.nl/sites/default/files/ kennisdocument/STR-INKST-art-005-bl.pdf. (Accessed on 20 September 2012.)

Garcia, R.H. 2009. International Public Procurement: a guide to best practice. Globe business Publishing Ltd. United Kingdom.

Gilbert, M. 2008. Public procurement in developing countries. Conference proceedings of 3rd International Public Procurement Conference held in The Netherlands. Amsterdam. 1055-64.

Handfield, R. Monczka, R. Giunipero, L.C. \& Patterson, J.L. 2011. Sourcing and Supply chain management. Ontario: South-Western.

Holmberg, S. 2000. A systems perspective on supply chain measurements. International Journal of Physical Distribution \& Logistics Management, 30(10): 847-68.

Hugo, W.M.J. \& Badenhorst-Weiss, J.A. 2011. Supply chain management: Logistics in perspective. Pretoria: Van Schaik. 
International Education Association of South Africa (IEASA). 2009. Higher Education in Context: The Guide to South African Higher Education. Available from: www.ieasa.studysa. org. (Accessed 23 August 2012).

Immerwahr, J. \& Johnson, J. 2007. Squeeze play: How parents and the public look at higher education today. San Jose, CA: The National Center for Public Policy and Higher Education.

Ireland, R.D. \& Webb, J.W. 2007. Strategic entrepreneurship: creating competitive advantage through streams of innovation. Business Horizons 50: 49-59.

Kraljic, P. 1983. Purchasing must become supply management. Harvard Business Review, 61(5): 109-17.

Lau, A.K.W. 2007. Educational supply chain management: a case study. Emerald Group Publishing, 15(1): 15-27.

Mahmood, S.A.I. 2010. Public Procurement and corruption in Bangladesh confronting the challenges and opportunities. Journal of Public Administration and Policy Research, 2 (6): 103-11.

McCruden, C. 2007. Buying social justice: Equality, government procurement, and legal change. New York, Oxford University Press.

Mdumbe, M.F. 2003. The meaning of 'organ of state' in the South African law. Unpublished master's thesis. Pretoria: University of South Africa.

Migiro, S.O. \& Ambe, I.M. 2008. Evaluation of the implementation of public sector supply chain management and challenges: A case study of the central district municipality, North West Province, South Africa; African Journal of Business Management, 2(12): 230-42.

Mkhize, Z. 2004. Supply Chain Management: Transforming Government Procurement System. Paper presented in Durban Conference, Republic of South Africa: 22-23 November.

Monczka, R.M. Handfield, R.B. Guinipero, L.C. \& Patterson, J.L. 2009. Purchasing and Supply Chain Management. South-Western. Cengage learning.

Monczka, R.M. Handfield, R.B. Guinipero, L.C. Patterson, J.L. \& Waters, D. 2010. Purchasing and Supply Chain Management. South-Western. Cengage learning.

Mthembu, T. 2009. University governance and the knowledge economy: Reconditioning the engine of development. Development Planning Division Working Paper Series No.3, DBSA: Midrand. 
National Treasury. Republic of South Africa. 2003. 'Policy Strategy to guide uniformity in Procurement reforms processes in government'.

National Treasury. Republic of South Africa. 2005. 'Supply Chain Management: A guide for accounting officers and municipal entities'.

National Treasury. Republic of South Africa. 2011. Implementation guide preferential procurement regulations, pertaining to the Preferential Procurement Policy Framework Act No 5 of 2000.

National Treasury. Republic of South Africa. 2012. Estimates of National Expenditure.

Nelson, D. Moody, P. \& Stegner, J.R. 2005. The incredible payback: Innovative sourcing solutions that deliver extraordinary results. AMACOM American Management Association, United States of America.

Odhiambo, W. Kamau, P. 2003. Public Procurement: Lessons from Kenya, Tanzania and Uganda. OECD Development Centre Working Paper No. 208.

Reck, R.F. Long, B.G. 1988. Purchasing: A competitive weapon. Journal of Purchasing and Materials Management. 24(3): 2-8.

Rudzki, R.A. Smock D.A. Katzorke, M. Stewart, S. 2006. Straight to the bottom line: an executive's roadmap to world class supply management. J. Ross Publishing, Florida.

SAMDI. 2005. Supply Chain Management: A guide for accounting officers and municipal entities. Course Manual.

Schuh, C. Raudabaugh, J.L. Kromoser, R. Strohmer, M.F. \& Triplat, A. 2012. The Purchasing chessboard: 64 Methods to Reduce Costs and Increase Value with Suppliers. New York: Springer Science Business Media, LLC.

Smock, D. A. Rudzki, R. A. and Rogers, S. C. 2007. On-demand supply management: world class strategies, practices and technology. J. Ross publishing Inc, Fort Lauderdale.

Sollish, F. \& Semanik, J. 2007. The Procurement and Supply Manager's Desk Reference. John Wiley \& Sons, Inc Hoboken, New Jersey.

Sysons, R. 1992. Improving purchase performance. Pitman, London. 
Tucker, A.L. Nembhard, I.M. \& Edmondson, A.C. 2007. Implementing new practices: an empirical study of organizational learning in hospital intensive care units. Management Science, 53(6), 894-907.

Wellstein, B. \& Kieser, A. 2011. Trading 'best practices' - a good practice? Industrial and Corporate Change, 1-37.

Table of acronyms

\begin{tabular}{|l|l|}
\hline BBBEEA & Broad-Based Black Economic Empowerment Act \\
\hline CPAR & Country Procurement Assessment Review \\
\hline IEASA & International Education Association of South Africa \\
\hline PBP & Procurement Best Practices \\
\hline PFMA & Public Finance Management Act \\
\hline PPPFA & Preferential Procurement Policy Framework Act \\
\hline PURCO & Purchasing Consortium Southern Africa \\
\hline SAPHEI & South African Public Higher Education Institution \\
\hline SCM & Supply Chain Management \\
\hline
\end{tabular}

